\title{
EDUKASI METODE DEMONSTRASI DAN ROLE PLAY TERHADAP PENGETAHUAN POLISI LALU LINTAS (POLANTAS) TENTANG PERTOLONGAN PERTAMA GAWAT DARURAT KECELAKAAN LALU LINTAS
}

\author{
Fauzan Alfikrie ${ }^{1}$, Uti Rusdian Hidayat ${ }^{1}$, Eka Putri Wahyuningtyas ${ }^{1}$ \\ ${ }^{1}$ STIKes YARSI Pontianak, Pontianak, Indonesia
}

\author{
Data Penulis \\ Fauzan Alfikrie: Keperawatan Medikal Bedah dan Gawat Darurat, Program Studi Pendidikan \\ Profesi Ners. STIKes YARSI Pontianak, Jalan Panglima A’im, Kota Pontianak. \\ Email: ners.fauzan06@gmail.com
}

\begin{abstract}
Abstrak
Pertolongan pertama penting diberikan kepada korban yang mengalami kecelakaan lalu lintas untuk memberikan keselamatan dan mencegah timbulnya kecacatan. Pendidikan kesehatan dengan metode demonstrasi dan role play diharapkan dapat meningkatkan pengetahuan polantas dalam memberikan pertolongan pertama pada korban kecelakaan lalu lintas. Tujuan penelitian ini adalah mengidentifikasi pengaruh pendidikan kesehatan dengan metode demonstrasi dan role play terhadap pengetahuan polantas tentang pertolongan pertama pada korban kecelakaan lalu lintas. Penelitian quasi experiment dengan menggunakan one group pretest dan post test without control group design. Besar sampel yaitu 15 orang dianalisis menggunakan uji statistik Wilcoxon. Hasil penelitian menunjukan ada pengaruh edukasi dengan metode demonstrasi dan roleplay terhadap pengetahuan pada polantas $(\alpha 0,001)$. Pendidikan kesehatan merupakan upaya peningkatan pengetahuan polisi lalu lintas tentang pertolongan pertama gawat darurat pada korban kecelakaan.

Kata Kunci : Pendidikan Kesehatan, Demonstrasi, Role Play, Pengetahuan
\end{abstract}

\begin{abstract}
First aid is important for victims who had traffic accidents to gave the safety and prevent disability. Health education with demonstrations and role play is expected to increase police knowledge in proved first aid to victims of traffic accidents. The purpose of this study was to identify the effect of health education on demonstration and role play methods on the knowledge of traffic police regarding first aid to victims of traffic accidents. Quasi-experimental research using One Group pretest and Post test without Control group design. The sample size is 15 people analyzed using the Wilcoxon statistical test. The results showed that there was an effect of education with the demonstration method and roleplay on knowledge in the traffic police ( $\alpha$ 0.001). Health education is an effort to increase the knowledge of traffic police about emergency first aid to accident victims.

Keywords $\quad$ : Health Education, Demonstration, Role Play, Knowledge
\end{abstract}

\section{Pendahuluan}

Kecelakaan lalu lintas adalah suatu peristiwa di jalan yang tidak diduga dan tidak disengaja melibatkan kendaraan dengan atau tanpa pengguna jalan lain yang mengakibatkan korban manusia dan/atau kerugian harta benda. (UU No. 22 tahun 2009). Tidak jarang kecelakaan lalu lintas dapat menimbulkan korban luka ringan (slight injury), korban luka berat (serious injury) dan korban meninggal (PP No. 43 tahun 1993. Data yang dikeluarkan World Health Organization (WHO)
menunjukan India menempatkan urutan pertama negara dengan jumlah kematian terbanyak akibat kecelakaan lalu lintas. Angka kematian global saat ini tercatat mencapai angka 1,24 juta per tahun atau 3400 orang meninggal setiap harinya akibat kecelakaan lalu lintas di dunia. Angka tersebut di prediksi akan terus meningkat apabila tidak ada langkah nyata yang diambil untuk mengantisipasinya. Diprediksi pada tahun 2020, korban meninggal dunia akibat kecelakaan lalu lintas dapat mencapai hingga 1.900.000 orang (Irvan,2016).

Kejadian kecelakaan lalu lintas di Indonesia tahun 2017 mencapai angka 98.419 
kasus yang menyebabkan korban meninggal mencapai 25.859 jiwa dan luka berat mencapai 16.159 jiwa (BPS, 2018). Sedangkan di Kota Pontianak dari tahun 2016 ke 2017 mengalami penurunan. Pada tahun 2016 tercatat sebanyak 632 kasus kecelakaan, dengan korban meninggal sebanyak 118 orang, kecacatan atau kategori Luka berat sebanyak 370 orang, dan luka ringan sebanyak 430 orang. Di tahun 2017, tercatat sebanyak 441 kasus kecelakan, dengan korban meninggal sebanyak 89 orang, kecacatan atau luka berat sebanyak 234 orang, dan luka ringan sebanyak 334 orang (Laporan Anatomi Laka Tahun 2016-2017).

Korban akibat kecelakaan lalu lintas bersifat gawat darurat, sehingga membutuhkan pertolongan secara cepat pada lokasi kejadian untuk mencegah morbiditas dan mortalitas korban. Pertolongan yang diberikan dilokasi kejadian merupakan bagian dari prehospital care yang bertujuan untuk menurunkan risiko kematian akibat trauma. Disini Petugas kepolisian memegang peranan yang sangat penting dalam memberikan pertolongan pertama kepada korban kecelakaan jika terdapat keterbatasan petugas medis untuk memberikan pertolongan (Ulya, Dkk, 2017).

Pertolongan pertama merupakan perawatan yang diberikan segera pada orang yang cedera atau mendadak sakit dengan tujuan untuk memberikan bantuan sementara sampai mendapatkan perawatan medis yang semestinya serta mengurangi mortalitas dan kematian (Thygerson, 2011). Namun, pada kenyataannya pertolongan korban kecelakaan sering tidak tepat seperti kesalahan dalam memindahkan posisi korban, melakukan penanganan luka yang tidak tepat sehingga petugas penolong cenderung tidak aman dan dapat tertular berbagai penyakit. Oleh sebab itu tindakan pertolongan pertama harus dibekali dengan pengetahuan dan keterampilan yang baik, tepat dan cepat serta akurat untuk mengenali masalah yang dialami oleh korban kecelakaan lalu lintas.

Pengetahuan merupakan hasil pengindraan manusia atau hasil tahu seseorang terhadap objek melalui indra yang dimilikinya. Pengetahuan dapat diperoleh melalui pendidikan. Pendidikan merupakan proses perubahan sikap dan perilaku seseorang atau kelompok melalui pengajaran dan pelatihan (Notoatmodjo, 2010). Pendidikan kesehatan merupakan upaya untuk meningkatkan pengetahuan masyarakat tentang kesehatan. Dalam membantu meningkatkan pengetahuan, biasanya diberikan pengajaran melalui pendidikan kesehatan salah satunya dengan metode demonstrasi dan roleplay tentang cara memberikan pertolongan pertama secara tepat.

Pendidikan kesehatan dengan model pelatihan pertolongan pertama pada korban kecelakaan dengan metode ceramah dan leaflet meningkatkan pengetahuan kepada siswa kelas VII. Buamona dkk (2017), juga menjelaskan bahwa pendidikan kesehatan dengan metode ceramah tentang Bantuan Hidup Dasar (BHD) pada kecelakaan lalu lintas meningkatkan pengetahuan terhadap siswa SMA. 
Hasil penelitian lainnya oleh Dahlan dkk, (2014), pendidikan kesehatan tentang Bantuan Hidup Dasar (BHD) berpengaruh signifikan terhadap peningkatan pengetahuan tenaga kesehatan. Pangaribuan dkk (2017), juga menunjukkan bahwa pendidikan kesehatan terhadap pengetahuan Bantuan Hidup Dasar (BHD) pada perawat pelaksana dengan menggunakan metode audiovisual dan alat peraga meningkatkan pengetahuan perawat.

Peningkatan pengetahuan pada petugas khusus terutama polisi lalu lintas merupakan bagian penting dalam unsur keselamatan pasien yang mengalami trauma. Polisi merupakan orang pertama yang melakukan pertolongan pertama kali terhadap korban kecelakaan. Oleh sebab itu, penulis tertarik untuk melakukan penelitian tentang edukasi dengan metode demonstrasi dan role play terhadap pengetahuan polantas tentang pertolongan pertama korban kecelakaan lalu lintas.

\section{Metode Penelitian}

Penelitian ini mengguanakn desain quasy experiment dengan metode pre tes dan post tes tanpa kelompok kontrol. Sampel yang dipilih telah sesuai dengan kriteria penelitian yaitu petugas yang aktif, telah bekerja sebagai polisi lalu lintas minimal satu tahun dan pernah menolong korban kecelakaan. Sampel penelitian dipilih secara purposiv sampling. Jumlah sampel pada penelitian ini adalah 15 responden.

Instrumen penelitan yang digunakan pada penelitian ini adalah kuesioner pengetahuan yang terdiri dari 16 item pertanyaan yang mencakup safety, initial assessment, dan evakuasi. Instumen ini telah dilakukan uji validitas dan reliabilitas. Uji validitas kepada 30 responden diperoleh nilai $\mathrm{r}$ hasil berentang antara 0,364-0,789 (> r tabel; 0,361) dan reliabilitas dengan nilai alpa Cronbach 0,83. Hasil tersebut menunjukan bahwa 16 item pertanyaan dinyatakn valid dan reliabel. Penelitian ini juga menggunakan peralatan gawat darurat seperti phantom CPR, papan spinal panjang, collar neck, ambu bag, spalk, dan kain segitiga.

Pemateri merupakan instruktur HIBGABI yang telah tersertifikasi. Peneliti melakukan apersepi dengan menjalaskan tujuan penelitian, luas lingkup materi yang akan disampaikan dan metode yang digunakan. Hal ini dilakukan untuk menghindari bias salama penelitian berlansung.

Data dikumpulkan dengan melakukan pretest kepada responden yang sesaui dengan kriteria. Responden diberikan kesempatan mengisi kuesioner pengetahuan tentang PPGD kecelakaan lalu lintas selama 15 menit. Selanjutnya setelah kuesioner terisi semua, peneliti melanjutkan kegiatan dengan memberikan pendidikan kesehatan dengan metode demonstrasi dan role play tentang pertolongan pertama pada korban kecelakaan lalu lintas materi disampaikan selama 60 menit kemudian dilanjutkan dengan demonstrasi PPGD pada korban kecelakaan lalu lintas. Demonstrasi diberikan selama satu kali kemudian responden dibagi menjadi dua 
kelompok untuk melakukan role play secara bergantian. Setelah kegiatan selesai peneliti memberikan kuesioner posttest tentang pengetahuan polantas terhadap tindakan Pertolongan Pertama Gawat Darurat.

Penelitian ini telah mendapat persetujuan dari komisi etik STIKes YARSI Pontianak. Uji statistic untuk menilai perbedaan rata-rata sebelum dan sesudah intervensi menggunkan uji wilcoxon.

\section{Hasil Penelitian}

Hasil penelitian menunjukan rata-rata usia responden dalam penelitian ini adalah 30 tahun. Responden yang berpartisipasi dalam penelitian ini keseluruhan berjenis kelamin laki-laki. Sebagian besar responden memiliki pengalaman kerja lebih dari 10 tahun yaitu $66,7 \%$. Hasil penelitian ini juga menunjukan pendidikan terakhir responden adalah SMA sebanyak $80 \%$.

Hasil analisis perbedaan rata-rata pengetahuan responden sebelum dan setelah diberikan demonstrasi dan role play pada pengetahuan polisi lalu lintas tentang Pertolongan Pertama Gawat Darurat dijelaskan pada tabel 1.

Tabel 1. Uji Wilcoxon sebelum dan sesudah diberikan pendidikan kesehatan

\begin{tabular}{cccc}
\hline Pengetahuan & Median & $\begin{array}{c}\text { Std. } \\
\text { Deviation }\end{array}$ & $\boldsymbol{P}$ \\
\hline Sebelum & 9,67 & 0,258 & \multirow{2}{*}{$0,001^{*}$} \\
\hline Sesudah & 13,20 & 1,320 &
\end{tabular}

Uji Wilcoxon, 14 Subjek pengetahuan meningkat, 0 menurun, 1 tetap. *Bermakna
Hasil penelitian menunjukan bahwa 14 responden menujukkan pengetahuan yang meningkat setelah diberikan edukasi dengan metode demonstrasi dan role play. Median sebelum intervensi adalah 9,67 dan meningkat setelah diberikan intervensi dengan median 13,20. Hasil analisis menunjukkan terdapat perbedaan yang bermakna antara pengetahuan sebelum dan sesudah diberikan edukasi dengan nilai $p=0,001(<0,05)$.

\section{Pembahasan}

Hasil penelitian menunjukan adanya pengaruh pendidikan kesehatan dengan metode demonstrasi dan role play terhadap pengetehuan polisi lalu lintas. Edukasi dengan metode demonstrasi dan role play memberikan pengalalaman nyata bagi individu saat mengikuti pendidikan kesehatan. Metode demonstrasi merupakan metode penyajian pelajaran dengan memperagakan dan menunjukan kepada peserta tentang suatu proses, situasi atau benda tertentu, baik sebenarnya atau sekedar tiruan (Nasih \& Kholidah, 2009). Sedangkan metode role play atau bermain peran membuat peserta latihan menunjukkan karakter yang ditugaskan kepada mereka. Informasi mengenai situasi (misalnya, masalah kerja atau interpersonal) diberikan kepada peserta pelatihan. Peranan berbeda dari simulasi berdasarkan pilihan respons yang tersedia bagi peserta pelatihan dan tingkat detail situasi yang diberikan kepada peserta pelatihan (Noe, 2010) 
Hasil penelitian yang dilakukan Nurhanifah (2017), bahwa pendidikan kesehatan memberikan pengaruh terhadap tingkat pengetahuan pertolongan pertama pada kecelakaan di sekolah pada siswa kelas VII. Penelitian Pangaribuan Dkk (2017) adanya pengaruh media pendidikan kesehatan terhadap pengetahuan bantuan hidup dasar (BHD) pada perawat pelaksana dirumah sakit TK. II Putri Hijau. Begitu juga pada hasil penelitian Dahlan dkk (2014) bahwa adanya pengaruh pendidikan kesehatan tentang bantuan hidup dasar (BHD) terhadap tingkat pengetahuan tenaga kesehatan di Puskesmas Wori Kecamatan Wori Kabupaten Minahasa utara.

Kelebihan metode demonstrasi adalah dapat membuat pengajaran menjadi lebih jelas dan konkret, sehingga menghindari verbalisme, peserta lebih mudah memahami pelajaran, proses belajar menjadi lebih menarik dan siswa dirangsang menjadi lebih aktif mengamati, menyesuaikan antara teori dengan kenyataan (Djamarah, 2010).

Pengetahuan dapat diperoleh melaui pendidikan dan pelatihan (Hariandja, 2007). Edukasi dengan metode demostrasi dan role play yang diberikan mampu meningkatkan pengetahuan responden tentang pertolongan pertama pada korban kecelakaan lalu lintas. Metode yang digunakan bersifat mempraktekan atau memperagakan secara langsung kepada responden.

Metode demonstrasi dirasa lebih tepat digunakan untuk menyampaikan materi tentang pertolongan pertama supaya responden selain mendapatkan informasi, responden juga mendapatkan gambaran tentang tehnik pertolongan pertama yang tepat dan bisa mereka terapkan saat akan menolong masyarakat yang mengalami kecelakaan lalu lintas.

\section{Kesimpulan}

Hasil penelitian menunjukan adanya pengaruh pendidikan kesehatan dengan metode demonstrasi dan role play yang bermakna terhadap peningkatan pengetahuan responden tentang pertolongan pertama pada korban kecelakaan lalu lintas. Penelitian ini memiliki keterbatasan pada karakteristik responden dimana seluruh responden pada penelitian ini adalah laki-laki. Penelitian selanjutnya dapat mengguakan metode yang sama kepada responden dengan karakteristik yang berpasangan.

\section{Ucapan Terima Kasih}

Penulis berterima kasih kepada tim HIPGABI Provinsi Kalimantan Barat, responden, Pembimbing, staf dosen STIKes YARSI Pontianak, dan asisten peneliti yang telah bersedia meluangkan waktu dan memberikan dukungan kepada peneliti.

\section{Referensi}

Baumona, S., $d k k$ (2017). Pengaruh pendidikan kesehatan terhadap tingkat pengetahuan bantuan hidup dasar (BHD) pada kecelakaan lalu linntas pada siswa SMA Negeri 1 Sanana Kabupaten Kepulauan 
Sula Maluku Utara. Jurnal Keperawatan Unsrat. 5 (1).

BPS. (2018). Data Kecelakaan 2017. https://databoks.katadata.co.id/datapubl ish/2018/09/21/sepanjang-2017-terjadi98-ribu-kali-kecelakaan-lalu-lintas1 diakses tanggal 4 Maret 2018.

Dahlan, S., Kumaat, L., \& Onibala, F. (2014). Pengaruh Pendidikan Kesehatan Tentang Bantuan Hidup Dasar (BHD) Terhadap Tingkat Pengetahuan Tenaga Kesehatan di Puskesmas Wori Kecamatan Wori Kabupaten Minahasa Utara, Ejournal Keperawatan (e-Kp). Vol. 2(1).

Djamarah, S.B., \& Zain, A. (2010). Strategi Belajar Mengajar. Jakarta: Rineka Cipta.

Hariandja, M.T.E. (2007). Manajemen Sumber Daya Manusia; pengadaan pengembangan, pengkompensasian, dan peningkatan produktifitas pegawai. Jakarta: Grasindo.

Irvan, B.S. (2016). 5 Negara dengan Tingkat Kecelakaan Lalu Lintas Tertinggi. Diaksies di https://media.iyaa.com/article/2016/04/ ini-5-negara-dengan-tingkatkecelakaan-lalu-lintas-tertinggi-didunia-3440575_9293.html diakses tanggal 4 Maret 2018 pukul 21.33

Nasih, A.M., \& Kholidah, L.N. (2009). Metode dan Tehnik Pembelajaran Agama Islam. Bandung: Refika Aditama.
Noe, R.A. (2010). Employ Training and Depelovement. $5^{\text {th }}$ ed. United States; The McGraw-Hill Companies

Notoatmodjo, S. (2010). Promosi Kesehatan Teori \& Aplikasi. Jakarta: Rineka Cipta Nurhanifah, D. (2017). Pengaruh Pendidikan Kesehatan Terhadap Tingkat Pengetahuan Pertolongan Pertama Pada Kecelakaan di Sekolah Pada Siswa Kelas VII. Caring Nursing Journal. Vol 1(1).

Pangaribuan, R., Slagian, M.T., \& Slralt, A. (2017). Pengaruh Media Pendidikan Kesehatan Terhadap Pengertahuan Bantuan Hidup Dasar (BHD) Studi Eksperimen Pada Perawat Pelaksana Di Rumah Sakit TK. II Putri Hijau Medan. Jumantik. Vol. 3(1).

Peraturan Pemerintah RI Nomor 43 Tahun 1993. Tentang Prasarana dan Lalu Lintas Jalan. Lembaga Negara Republik Indonesia Tahun 1993 Nomor 60. Jakarta: 1993

Ulya, I., Ratnawati, R., \& Kumboyono. (2017). Studi Fenomenologi: Pengalaman Petugas Kepolisian Dalam Memberikan Tindakan Pertolongan Pertama Korban Kecelakaan Lalu Lintas. Majalah Kesehatan. Vol. 4(4).

Thygerson, A. (2011). First Aid Pertolongan Pertama Edisi Lima. Jakarta: Erlangga Undang-Undang No. 22 tahun 2009. Tentang Lalu Lintas dan Angkatan Jalan. Yogyakarta: Pustaka Yustisia. 